\title{
Use of Remote Lab for Online and Real time Practicum at Vocational School in Indonesia
}

\author{
https://doi.org/10.3991/ijoe.v16i05.13201 \\ Hendra Jaya ${ }^{(\varpi)}$, Sapto Haryoko, Lu’mu, Putri Ida \\ Universitas Negeri Makassar, Makassar, Indonesia \\ hendrajurnalegmail.com
}

\begin{abstract}
The Aims of this paper is to analyze the influence of Remote Lab on overcoming the limitation of practicum facilities. This study uses qualitative research methods. In this study, the researchers conducting a study of the use of remote labs in overcoming the unavailability of laboratory equipment. 1). The completeness of practicum equipment available at SMKs is still inadequate, only around $30 \%$. Some students stated that when carrying out practical activities, each tool used by 4 students simultaneously made the practicum process not run effectively and often there was discrimination only intelligent students who could complete the sequence, then some students also stated that the existing components many have been damaged. Another statement expressed by students that not all productive subjects can be practiced because of limited equipment that can be caused by several factors including: a) inadequate school budget; b) tools and practice materials that are difficult to obtain; 2) The Remote LAB application sends data at any time when selecting a Lab, selecting a Gate, and selecting input from a gate. The output of the gate will be measured using a multi-meter and oscilloscope and will be monitored directly via YouTube streaming, so that it can be monitored in real time on the Remote LAB Android application; 3) Practical experience does not have to be identical in a laboratory room on a supervised Schools. Students receive tangible observations using real equipment to arrive at concrete conclusions, as well as assessing them in a physical laboratory with equipment so that it will be beneficial to improve their laboratory abilities.
\end{abstract}

Keywords - Remote-lab, Practicum Facilities.

\section{Introduction}

The use of hands-on laboratories can cause students to experience psychological barriers in carrying out practical work. In addition to being expensive in procuring materials and operating costs and less flexible, hands-on laboratories also make students less comfortable at work, such as the emergence of fear of damage to the equipment to be used [1]. Such conditions can cause a decrease in student motivation in participating in practical activities. At present a variety of computer applications have been developed to support the implementation of $\mathrm{V}$-Labs which are believed by education experts to increase flexibility in terms of time allocation and place for practicing. Practicum activities with V-Lab can provide an efficient level of financing because it is based on 
simulators created using computer programs. Besides being able to increase efficiency in financing and more flexibility, the use of simulators to support V-Lab implementation can increase student motivation in carrying out work in the laboratory [2].

Another demand of a practicum activity is the existence of collaborative work among students. Collaborative work in practical activities is very important because it is able to motivate individuals in group work, and is able as a means for mutual learning between individuals [3]. V-Lab can be implemented easily and at low cost. The use of VLab also provides a positive perception of the aspects of product appearance and ease of operation and can increase student motivation in carrying out practicum [4].

Virtual Laboratory is a computer software that has the ability to do mathematical modeling of computer equipment that is presented through a simulation. Virtual laboratories are needed to strengthen understanding of concepts in the learning process. The Virtual Laboratory is not a substitute but a part of the real Laboratory that is used to complement and correct existing weaknesses [5]. The weakness of VLAB is that the Virtual Laboratory does not provide real field experience [6].

The Remote Lab (RL) concept is a relatively new concept built but the number is exponentially increasing due to the latest technological advancements and the availability of tools to design it. Remote labs are the best alternative for working in a real laboratory because if well designed they can offer students: 1) tele-presence in the laboratory (tele-presence); 2) Can experiment on real equipment; 3) can collaborate; 4) Learning by trial and error; 5) can conduct analysis on real experimental data; and 6) Flexibility in choosing the time and place to conduct experiments. The main advantages and disadvantages of each type of laboratory are summarized in Table 1.

The main advantages and disadvantages of each type of laboratory are summarized in Table 1.

Table 1. Comparison Of Advantages And Disadvantages Of Real Labs, Virtual Labs, And Remote Labs [7]

\begin{tabular}{lll}
\hline Laboratory Type & Advantages & Disadvantages \\
\hline Real & $\begin{array}{l}\text { realistic data } \\
\text { interaction with real equipment } \\
\text { collaborative work } \\
\text { interaction with supervisor }\end{array}$ & $\begin{array}{l}\text { time and place restrictions } \\
\text { requires scheduling } \\
\text { expensive } \\
\text { supervision required }\end{array}$ \\
\hline Virtual & $\begin{array}{l}\text { good for concept explanation } \\
\text { no time and place restrictions } \\
\text { interactive medium }\end{array}$ & $\begin{array}{l}\text { idealized data } \\
\text { lack of collaboration } \\
\text { no interaction with real equipment }\end{array}$ \\
& low cost & only "virtual presence" in the lab \\
\hline Remote & interaction with real equipment \\
& $\begin{array}{l}\text { calibration } \\
\text { realistic data } \\
\text { no time and place restrictions } \\
\text { medium cost }\end{array}$ & \\
\hline
\end{tabular}

The use of smartphones is now increasingly popular and is one of the most common consumer devices. This technology has also changed the role of education and educational programs in higher education participation in learning. Today's mobile applications are more flexible and can integrate existing services using web-based integration. 
Some interesting learning tools are designed and developed by integrating emerging technologies such as motion sensors, cameras, global positioning systems, Wi-Fi, Bluetooth, and others [8]. Various interesting applications and methods will continue to be integrated to create an effective learning environment in this research integrating Android Smartphones to control practicum equipment at a distance. Thus it will provide assistance to students not to be present again in the laboratory room to carry out practical activities. Taking into account the various demands of the implementation of practicum in the electronics field, it is necessary to develop Remote Labs that can provide online collaborative work facilities with more attractive devices so that later they can facilitate students in the practicum process so that they will be motivated [9], thereby affecting their competence.

\subsection{Practicum}

According Surakhmad [10] states that the experiment / practicum is a very effective educational interaction method to answer questions such as How is the process? In what elements? Which method is the best? How can the truth be known through inductive observation? The practicum method is a learning process where students do and experience themselves, follow the process, observe objects, analyze, prove and draw conclusions of an object, state and process of the material being studied [11]. Experiment is a trial or special observation made to confirm or disprove something doubtful [12].

\subsection{The remote laboratory concepts}

Remote Lab is a tool or device designed to teach collaborative work skills [13], because it offers an interesting perspective for social and collaborative based learning. However, the remote lab separates users from real work tables and tools. Thus, the teleoperating method of remote lab equipment requires an efficient level and interactivity and clarity to the user to give the impression of truly being in a laboratory.

Remote Lab can be a complementary resource for practical learning that is useful for laboratory activities on a "Hands-on", because it allows for monitoring or monitoring experiments that run remotely (online) [14][15]. Almost all laboratories in the fields of science and engineering have been mediated by computers [1]. As such, there are many lab devices today which are operated through a computer-based interface. Thus, the nature of accessing lab equipment may not differ greatly, whether students make physical contact or interact remotely through a virtual interaction panel.

\section{Research Method}

This study uses qualitative research methods. The qualitative research is an activity of collecting, analyzing, interpreting data, and reporting of interpretation result [16]. Content analysis is one of the qualitative research methods used to analyze and interpret textual data content [17]. The data analysis techniques used refers to the data analysis model by Miles \& Huberman [18], including collection, reduction, presentation of data, 
and conclusions. In this study, the researchers conducting a study of the use of remote labs in overcoming the unavailability of laboratory equipment.

\section{$3 \quad$ Results and Discussion}

Preliminary research conducted by researchers to obtain an overview of the needs of vocational high school students (SMK) relating to the implementation of practicum in schools. The first step taken by the researcher is to analyze the students' needs of the practical facilities and infrastructure at school. To analyze the availability of facilities and infrastructure and the needs of students, a needs analysis instrument is used which contains several indicators including the completeness of facilities and infrastructure in schools, the adequacy of practicum time in a real laboratory. In addition to distributing questionnaires there were also observations, direct observations and interviews with subject teachers related to digital electronics practicum. This activity was carried out by involving 2 Vocational High Schools in Makassar, one State Vocational School and one private Vocational School involving 64 respondents. The distribution of questionnaires to the two schools was carried out at different times with 30 respondents of SMKN 2 students and 30 respondents from SMK Muh 2 Bontoala. For SMKN 2 involving 2 teachers, and in SMK Muhammadiyah 2 Bontoala involving 2 teachers. The results of the analysis of the 60 respondents are shown in Figure 1.

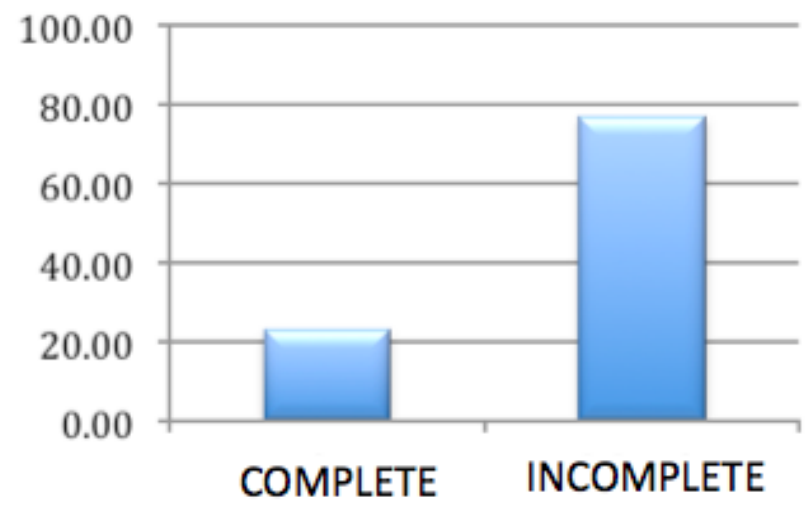

Fig. 1. Graph of completeness of practical equipment in SMK

The graph in Figure 1 shows that the completeness of practicum equipment available at SMKs is still inadequate, only around $30 \%$. Some students stated that when carrying out practical activities, each tool used by 4 students simultaneously made the practicum process not run effectively and often there was discrimination only intelligent students who could complete the sequence, then some students also stated that the existing components many have been damaged. Another statement expressed by students that not all productive subjects can be practiced because of limited equipment that can be 
caused by several factors including: a) inadequate school budget; b) tools and practice materials that are difficult to obtain.

Furthermore, based on observations and interviews with teachers conducted in several schools, including schools in the province of D.I. Yogyakarta namely SMKN 2 Depok Sleman Yogyakarta, and several public and private SMKs in Makassar namely, Gunung Sari 1 Makassar SMKN, Muhammadiyah 2 SMKN Makassar, Pallangga 1 SMKN. Gowa, SMKN BPPKT RSBI Sul-cell, SMKN 3 Takalar district. Takalar, and SMKN 1 Galesong district. Takalar obtained the following information:

1. The practicum model used in SMK is the conventional model.

2. The teacher has not innovated in practical learning by including important components such as a brief explanation using multimedia before the practice begins

3. The teacher feels the time to give practice material to vocational students is still lacking compared to the topic of existing material.

As findings in observation, especially in the process of carrying out practical activities in SMKs, it is described as follows:

1. Students feel stiff and awkward in using practical tools for fear of damaging practicum equipment.

2. Teachers of practical subjects are less able to monitor the maximum practical activities carried out in groups, because the teacher is only passive.

3. The teacher is difficult to give an assessment of student practicum activities with limited equipment.

4. Practicum implementation is not running effectively due to limited equipment. A practice equipment is run by six vocational students.

5. Students find it difficult to know the concept of practicum material provided.

6. Motivation in practical learning is rarely given by the teacher.

7. Motivation of students in participating in practical activities is still low as seen from the average attendance during the implementation of practical learning and observations when practical activities are running. It seems that students are not serious in the process of carrying out activities.

8. The limitations of the laboratory room at the Vocational School with a large number of classes makes the time to carry out practical learning must be arranged in such a way through scheduling, so that there are certain times that are no longer effective for learning. For example, practicum activities carried out during the day, this can psychologically affect the mood of students in learning.

9. In some SMKs the arrangement of the laboratory space looks less presentable and ignores the aesthetic aspects of the space which include the color of the walls and lighting.

10. In some SMKs reference in the form of books supporting practice activities and data sheet books in the laboratory room are not available.

Implementation is focused on the Practice of Digital Electronics subjects. Digital Electronics is one of the Basic subjects in Electronics Department curriculum. In the audio video engineering department there are competencies that students must master, 
one of which is digital electronics competence. Digital electronics subjects consist of Basic Logic Gates (AND Gate, OR Gate, NAND Gate, NOR Gate, NOT Gate, EX-OR Gate, EX-NOR Gate).

The Remote Lab development process controlled via Android Smartphone begins with several stages, namely the needs analysis and preliminary studies to Evaluation. The Remote LAB application sends data to Firebase at any time when selecting a Lab, selecting a Gate, and selecting input from a gate. The data sent is string and integer data. In real time the Firebase database will read data that can only be read from the Remote LAB application, and in real time Firebase also presents data to be read by nodeMCU devices in the circuit (Fig 1). NodeMCU will read the selected gate string variable or data and integer data from the two gate inputs that have been remote from the Remote LAB application and are already in Firebase data. Existing data in nodeMCU will be forwarded to Arduino NANO via Serial USART communication (RX and TX), data currently on Arduino NANO will be forwarded again to the digital gate circuit. The output of the gate will be measured using a multimeter and oscilloscope and will be monitored directly via YouTube streaming, so that it can be monitored in real time on the Remote LAB application that has been loaded with a link from YouTube.

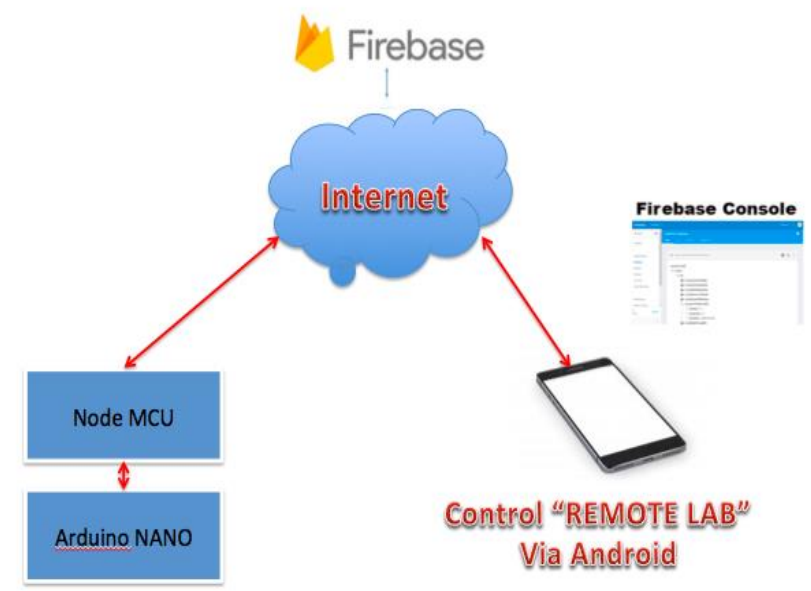

Fig. 2. Transfer Data and controlled experiment tools in the laboratory

\section{Analysis of the Effectiveness and Practical Use of Remote Lab}

One way to determine the effectiveness and practicality of the model is through the assessment of experts and practitioners based on the mastery of the theory and trials on respondents stated that the Remote-Lab model can be said to be effective or not. The results of the questionnaire assessment regarding product effectiveness are presented in Table 2 . 
Table 2. Remote Lab Effectiveness Assessment

\begin{tabular}{|l|c|l|}
\hline \multicolumn{1}{|c|}{ Effectiveness Indicator } & Average Score & \multicolumn{1}{c|}{ Criteria } \\
\hline Achieve increased performance (competence) & 4,2 & Effective \\
\hline Improving student performance for the completion of the material & 4,8 & Very Effective \\
\hline Average Overall Score & 4,56 & Very Effective \\
\hline
\end{tabular}

From Table 2 to assess the effectiveness of the Remote Lab product, several indicators of assessment regarding the achievement of work improvement (competency) are given, averaging a score of 4.2 or being in the effective category. Assessment of improving the performance of students for completing the material obtained a score of 4.8 or in very Effective category. Thus the overall overall effectiveness of the product obtained a mean score of 4.56 or is in the very effective category. This means that the products developed based on the responses of practical subjects meet the requirements for excellent product effectiveness.

Furthermore, to see the Remote Lab products developed in this study had met the practical requirements through several assessment indicators as presented in Table 8, the average score of overall aspects was 4.9 in the very practical category. Indicators stating practicality are elaborated with four assessment indicators as follows: First, Students can carry out and complete practicum objectively according to the flow and procedures in Remote-Lab scores obtained by a mean of 4.8 or are in the very practical category. This is very practical when compared to practicum in a conventional laboratory. One piece of equipment is practiced by $4-5$ students so that the completion of the practicum does not run objectively because only one person works and the others only watch, also in a conventional laboratory only intelligent students only can practice well. Second, the teacher can directly conduct an assessment and scoring of the results of student practicum stored in the Remote-Lab program database obtained a mean score of 5 or with a very practical category. Unlike the case in conventional laboratories the teacher must observe students one by one carefully the course of the practicum carried out by students. Third, Remote-Lab installed on Smartphone Participants can be directly accessed to do the practicum obtained by a score of 5 with a very practical category. Fourth, everything needed in the Remote Lab has been provided including tools and materials, measuring instruments, and data sheet books obtained a mean score of 4.8 with a very practical category. 
Table 3. Practical Assessment Of Remote Lab Products

\begin{tabular}{|l|c|c|}
\hline \multicolumn{1}{|c|}{ Practicality Indicator } & Average Score & Criteria \\
\hline $\begin{array}{l}\text { Students can carry out and complete practicum objectively ac- } \\
\text { cording to the flow and procedures in the Remote Lab }\end{array}$ & 4,8 & Very Good \\
\hline $\begin{array}{l}\text { Teachers can immediately conduct assessments and scoring of } \\
\text { student practicum results stored in the Remote-Lab program da- } \\
\text { tabase }\end{array}$ & 5 & Very Good \\
\hline $\begin{array}{l}\text { Remote-Lab installed on the Android Participants can be directly } \\
\text { accessed to do the practicum }\end{array}$ & 5 & Very Good \\
\hline $\begin{array}{l}\text { Everything needed in the Remote Lab has been provided includ- } \\
\text { ing tools and materials, measuring instruments, and data sheet } \\
\text { books }\end{array}$ & 4,8 & Very Good \\
\hline Average Overall Score & 4,9 & Very Good \\
\hline
\end{tabular}

The Remote Lab model of Digital Electronics is one form of interactive multimedia that can support conventional practice in real laboratories. After seeing the conditions and needs regarding the need for a learning strategy that is Distance Learning through Remote Lab, the next step is to search for models and designs that will be developed. Determination of the model is intended to choose the right model and look for references to the model to be developed. While the design determination concerns the software that will be used in developing Remote Lab-based learning in this case using Smartphone Android, the Arduino UNO Microcontroller, IoT, Android Applications, and Interface Arrangements. In doing the practicum by using the Remote lab. The device needs to be installed first. Furthermore, this virtual remote can be used online. to do a practicum measuring electric current and voltage, students still use the module as a guide in carrying out the practicum. Furthermore, measuring current and voltage, and waveforms with real devices are multimeters and oscilloscopes (picoscope), and it is possible to use other real equipment (Fig.3).

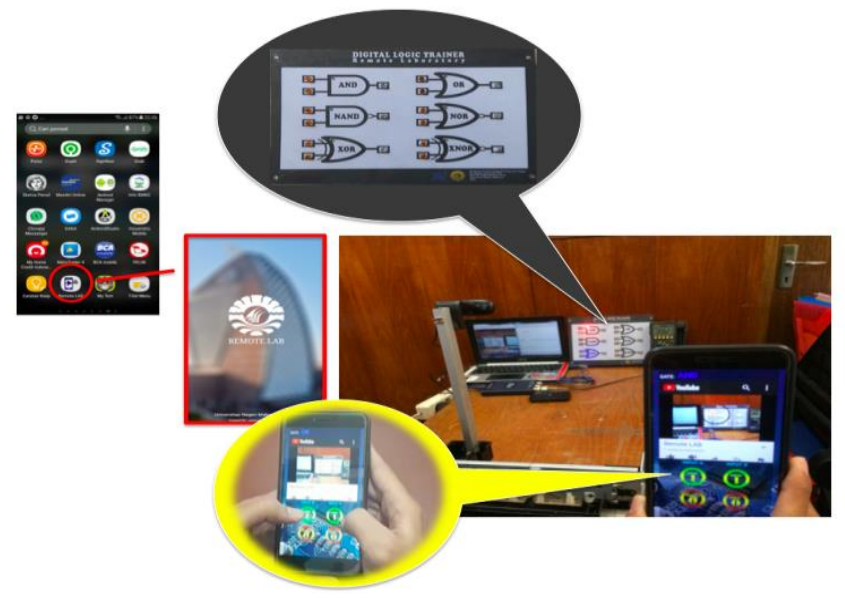

Fig. 3. Remote Lab as a Tool to Overcome the limitations of Practicum facilities without present in Real Lab (Designation of Value in Real-time with Real devices) 


\section{Conclusion}

1. The completeness of practicum equipment available at SMKs is still inadequate, only around $30 \%$. Some students stated that when carrying out practical activities, each tool used by 4 students simultaneously made the practicum process not run effectively and often there was discrimination only intelligent students who could complete the sequence, then some students also stated that the existing components many have been damaged. Another statement expressed by students that not all productive subjects can be practiced because of limited equipment that can be caused by several factors including: a) inadequate school budget; b) tools and practice materials that are difficult to obtain.

2. The Remote LAB application sends data at any time when selecting a Lab, selecting a Gate, and selecting input from a gate. The output of the gate will be measured using a multimeter and oscilloscope and will be monitored directly via YouTube streaming, so that it can be monitored in realtime on the Remote LAB Android application.

3. Practical experience does not have to be identical in a laboratory room on a supervised Schools. Students receive tangible observations using real equipment to arrive at concrete conclusions, as well as assessing them in a physical laboratory with equipment so that it will be beneficial to improve their laboratory abilities.

\section{Acknowledgement}

The authors would like to thank Professor Dr Husain Syam, M.TP., Rector of Universitas Negeri Makassar and Professor Dr Muhammad Yahya, M.Kes, M.Eng., Dean Faculty of Engineering of Universitas Negeri Makassar for the opportunity provided to carry out this research. DRPM Dikti Who have given the Research Grants. Their gratitude is extended to the Research Institute of Universitas Negeri Makassar for the facilitation of this research.

\section{$6 \quad$ References}

[1] J. Ma \& J. V. Nickerson, Hands-on, simulated, and remote laboratories: A comparative literature review. ACM Computing Surveys, 38/3, 2006, pp. 1-24. 2006. https://doi.org/10. $\underline{1145 / 1132960.1132961}$

[2] S. M. Alessi \& S. R. Trollip. Multimedia for learning: Methods and development, Boston, Allyn and Bacon. 2001.

[3] K. Kask. A study of science teacher development towards open inquiry teaching through an intervention progamme. Disertasi doktor, tidak diterbitkan, Universitas Tartu, Estonia. 2009.

[4] Muchlas. Pengembangan V-Lab Menggunakan Aplikasi Online Meeting dan Simulator Breadboard untuk Praktikum Elektronika Digital. Prosiding Pertemuan Ilmiah XXVIII HFI Jateng \& DIY, Yogyakarta, 26 April 2014 ISSN: 0853-0823. (2014).

[5] Purwanti Widhy. Pemanfaatan Laboratorium Virtual Pada Pembelajaran IPA. "Pelatihan Digitalisasi Perangkat dan Media Pembelajaran IPA Untuk Meningkatkan Kualitas 
Pembelajaran di Era Baru” di SMP 3 Muhammadiyah Depok. 2012. https://doi.org/10.30 870/jppi.v2i2.894

[6] Jaya, Hendra. Effectiveness the Use of thetual Laboratories in Improving Vocational Compotence and Character Behavior for Students Vocational High School in Makassar. International Journal of Applied Engineering Research (IJAER) ISSN: 1087-1090/0973-4562 Vol. 11 No. 9 :2016; Page. 6396-6401. 2016.

[7] Zorica Nedic. Remote Laboratories Versus Virtual and Real Laboratories. 33rd ASEE/IEEE Frontiers in Education Conference. 2003. https://doi.org/10.1109/fie.2003.126 $\underline{3343}$

[8] Kwang B. Lee, Raied Salman. The Design and Development of Mobile Collaborative Learning Application Using Android. Journal of Information Technology and Application in Education (JITAE). JITAE Vol.1 No. 12012 PP.1-8. World Academic Publishing. 2012.

[9] Ansari S. Ahmar \& Abdul Rahman. Development of teaching material using an Android. Global Journal of Engineering Education. Volume 19, Number 1, 2017. WIETE. 2017. https://doi.org/10.26858/gjeev19i1y2017p7376

[10] Surakhmad, Winarno, (1994). Pengantar penelitian ilmiah dan dasar metode teknik. Bandung: Tarsito.

[11] Djamarah, Syaiful Bahri \& Zain. Strategi belajar mengajar. Jakarta: Rineka Cipta. 2002.

[12] Adams, Scott. GOD Debris: a though experiment. New York: Andrew McMeel Publishing, LLC. 2001.

[13] Salaheddin Odeh, Eiman Ketaneh. "A Remote Engineering Lab for Collaborative Experimentation", International Journal of Online Engineering (iJOE), Vol 9, No 3. Pp. 10-18. 2013. https://doi.org/10.3991/ijoe.v9i3.2500

[14] Dieter Müller. Collaborative Remote Laboratories in Engineering Education: Challenges and Visions. Universität Bremen. Germany. 2007.

[15] Wael Farag." An Innovative Remote-Lab Framework for Educational Experimentation". International Journal of Online Engineering (iJOE). Vol 13, No 02. Pp. 68-86. 2017. https://doi.org/10.3991/ijoe.v13i02.6609

[16] S. Elo, M. Kääriäinen, O. Kanste, T. Pölkki, K. Utriainen, and H. Kyngäs, "Qualitative content analysis: a focus on trustworthiness," SAGE Open, pp.1-10, 2014. https://doi. org/10.1177/2158244014522633

[17] H.F. Hsieh and S.E. Shannon, "Three approaches to qualitative content analysis," Qualitative Health Research, vol 15, pp.1277-1288, 2005. https://doi.org/10.1177/104973230527 $\underline{6687}$

[18] M.B. Miles and A.M. Huberman, An expanded sourcebook qualitative data analisys, Thousand Oaks: SAGE Publication, 1994.

\section{$7 \quad$ Authors}

Hendra Jaya is a head of Vocational Education (D3 and D4 study programs) in Faculty of Engineering, Universitas Negeri Makassar (hendrajurnal@gmail.com). His research interest at the virtual laboratory, multimedia Learning, Android Application, and remote Laboratory.

Sapto Haryoko is a professor in Vocational Education in Faculty of Engineering, Universitas Negeri Makassar (sapto.haryoko@unm.ac.id). His research interest at the vocational school policy, virtual laboratory, multimedia Learning, Android Application, and remote Laboratory. 
Lu'mu is an Associate professor in Digital Electronics in Faculty of Engineering, Universitas Negeri Makassar (lumu@unm.ac.id). His research interest at Digital Electronics simulation, and multimedia Learning.

Putri Ida is a Lecturer in Data Communication and computer network Faculty of Engineering, Universitas Negeri Makassar (putriuda@gmail.com). His research interest at multimedia Learning.

Article submitted 2020-01-15. Resubmitted 2020-02-24. Final acceptance 2020-02-24. Final version published as submitted by the authors. 